\title{
Synthesis and Antimicrobial Activity of Some 1-arylideneamino-4-(4-chlorobenzylidene)-2-methyl- 1H-imidazolin-5(4H)-one Compounds
}

\section{CONG TIEN NGUYEN ${ }^{1 *}$, DAO THI HONG DINH ${ }^{1}$, THIN VAN NGUYEN ${ }^{2}$, GIANG DUC LE ${ }^{2}$ and HIEN CAO NGUYEN ${ }^{3}$}

${ }^{1}$ Faculty of Chemistry, Ho Chi Minh City University of Education, 280 An Duong Vuong St.,

District 5, 700000, Ho Chi Minh City, Vietnam.

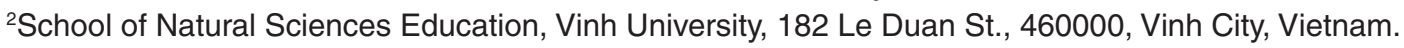
${ }^{3}$ Department of Chemical Technology, Ho Chi Minh City University of Food Industry, 140 Le Trong Tan St., Tan Phu District, 700000, Ho Chi Minh City, Vietnam.

${ }^{*}$ Corresponding author E-mail: congnt @ hcmue.edu.vn

http://dx.doi.org/10.13005/ojc/350245

(Received: August 09, 2018; Accepted: March 17, 2019)

\begin{abstract}
4-Chlorobenzylidene-2-methyl-(4H)-oxazol-5-one, which were prepared from 4-chlorobenzaldehyde and acetylglycine in reaction with hydrazine hydrate in ethanol gave 1-amino-4-(4-chlorobenzylidene)-2-methyl-1H-imidazolin-5(4H)-one. However, treatment of 4-chlorobenzylidene-2-methyl- $(4 \mathrm{H})$-oxazol-5-one with hydrazine hydrate in pyridine yielded 3-(4-chlorophenyl)propanohydrazide. Reaction of 1-amino-4-(4-chlorobenzylidene)-2-methyl-1Himidazolin-5(4H)-one with aromatic aldehydes gave eight corresponding Schiff's bases namely 1-arylideneamino-4-(4-chlorobenzylidene)-2-methyl-1H-imidazolin-5(4H)-ones. The structure of the 3-(4-chlorophenyl)propanohydrazide and the imidazoline-5-one compounds was confirmed by IR, ${ }^{1} \mathrm{H}-\mathrm{NMR},{ }^{13} \mathrm{C}$-NMR and MS spectral data. The Schiff's bases were tested for antimicrobial activities against several strains of Gram-positive, Gram-negative bacteria, molds and yeasts.
\end{abstract}

Keywords: 1-amino-4-(4-chlorobenzylidene)-2-methyl-1H-imidazolin-5(4H)-one, Antimicrobial activities, 4-chlorobenzylidene-2-methyl-(4H)-oxazol-5-one, Schiff bases, Spectral data.

\section{INTRODUCTION}

The imidazole nucleus has proven to be unusually fertile source of medicinal agents such as anticancer agents, antioxidant agents, antifungal agents and antimicrobial agents ${ }^{1,2,3}$.
Schiff's bases have been shown as biologically versatile compounds having antiinflammatory, anticonvulsant, antimalarial, antiviral, antifungal and antibacterial ${ }^{4,5}$. Recently, some Schiff's bases containing imidazole nucleus have been reported to possess various biological

This is an Open Access article licensed under a Creative Commons license: Attribution 4.0 International (CC- BY). Published by Oriental Scientific Publishing Company @ 2018 
properties like antioxidant and antimicrobial activity 6,7 . To contribute to the study of the synthesis and properties of the Schiff's bases, we report here the preparation of Schiff's bases containing imidazolin5-one moiety starting from 4-chlorobenzaldehyde and $\mathrm{N}$-acetylglycine via 4-chlorobenzylidene-2methyl-(4H)-oxazol-5-one first and then 1-amino4-(4-chlorobenzylidene)-2-methyl-1H-imidazolin$5(4 \mathrm{H})$-one. Next, the antimicrobial activities of the synthesized Schiff's bases were investigated. Besides that, in the present work, the transformations of the oxazole compound in solvents such as ethanol and pyridine were also mentioned.

\section{MATERIALS AND METHODS}

All reagents are of commercial quality and used without any further purification
Melting points were measured in open capillary tubes on a Gallenkamp melting point apparatus and are uncorrected. The IR spectra of synthesized compounds were recorded on FTIR-8400S-SHIMADZU spectrometer using $\mathrm{KBr}$ pellets. ${ }^{1} \mathrm{H}-\mathrm{NMR}$ was recorded on Bruker Avance spectrometer at $500 \mathrm{MHz}$ using a DMSO-d6 as a solvent and tetramethylsilane (TMS) as an internal standard, as well as the ${ }^{13} \mathrm{C}-\mathrm{NMR}, \mathrm{HSQC}, \mathrm{HMBC}$ spectra were recorded at $125 \mathrm{MHz}$. The $\mathrm{MS}$ spectra were recorded on a Bruker micrOTOF-Q 10187 spectrometer.

The synthesis of the Schiff's bases containing 2-methylimidazolin-5-one heterocycles were performed following the steps shown in Scheme 1.

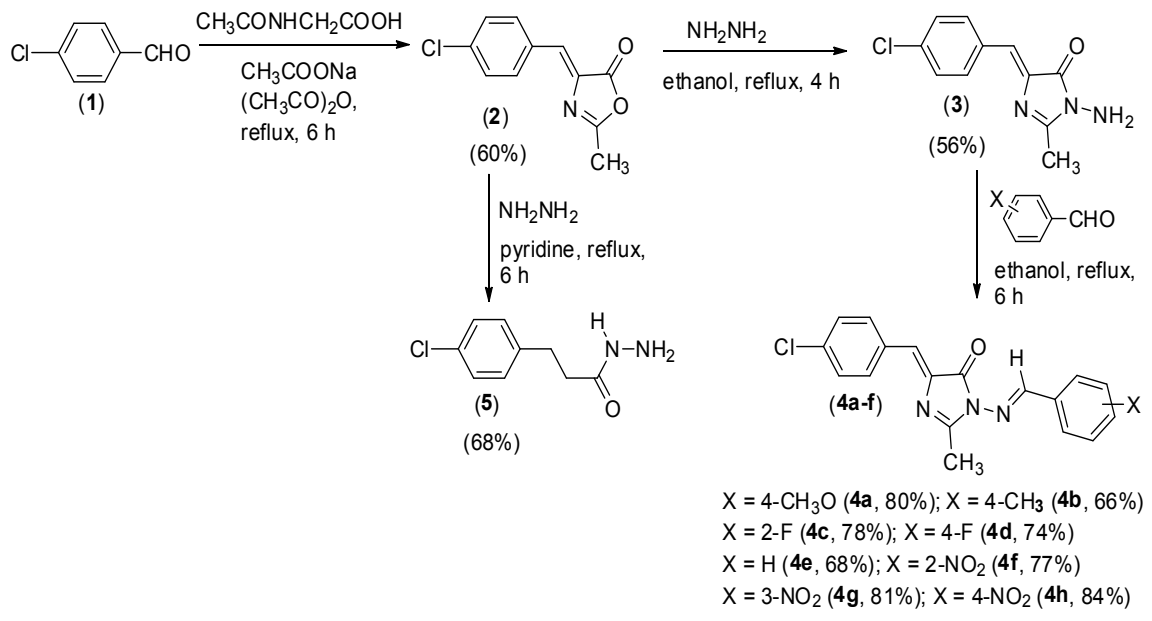

Scheme 1. Pathway for synthesis of 1-arylideneamino-4-arylidene-2-methyl-1H-imidazolin-5(4H)-one compounds

Synthesis of 4-(4-chlorobenzylidene)-2-methyloxazol$5(4 \mathrm{H})$-one (2)

Oxazole (2) was synthesized according to the procedure reported previously 8,9 : An equimolar mixture of 4-chlorobenzaldehyde (7.03 g, 0.05 $\mathrm{mol})$ and acetylglycine $(5.85 \mathrm{~g}, 0.05 \mathrm{~mol})$ in freshly distilled acetic anhydride $(25 \mathrm{~mL})$ containing fused anhydrous sodium acetate $(4.1 \mathrm{~g})$ was refluxed for 3 $\mathrm{h}$ and then cooled. The solid was triturated with cold saturated solution of sodium carbonate and filtered, washed with water, air dried and recrystallized from ethanol. Yield $60 \%, \mathrm{mp} .158-160^{\circ} \mathrm{C}$; IR $\left(\mathrm{v}, \mathrm{cm}^{-1}\right)$ : $1800,1772,1661,1605 ;{ }^{1} \mathrm{H}-\mathrm{NMR}(\delta, \mathrm{ppm}$ and $J$, $\mathrm{Hz}): 8.19(2 \mathrm{H}, \mathrm{d}, 3 \mathrm{~J}=8.0, \mathrm{ArH}), 7.57(2 \mathrm{H}, \mathrm{d}, 3 \mathrm{~J}=$ 8.0, ArH), $7.52(2 \mathrm{H}, \mathrm{d}, 3 \mathrm{~J}=8.5, \mathrm{ArH}), 7.23(1 \mathrm{H}, \mathrm{s}$, $\left.\mathrm{ClC}_{6} \mathrm{H}_{4} \mathrm{CH}=\right)$ and $2.39\left(3 \mathrm{H}, \mathrm{s}, \mathrm{CH}_{3}\right)$.
Synthesis of 1-amino-4-(4-chlorobenzylidene)-2methyl-1H-imidazolin-5-one (3)

To a solution of compound (2) (2.22 g, 0.0 l mole) in $50 \mathrm{ml}$ of absolute ethanol, hydrazine hydrate $50 \%$ (7.5 mL, 0.03 mole) was added and the reaction mixture was refluxed for 4.0 hours. On cooling, the formed precipitate was filtered off and crystallized from ethanol. Yield $56 \%$, mp. $192-193^{\circ} \mathrm{C}$; IR $\left(v, \mathrm{~cm}^{-1}\right)$ : 3318, $3209(\mathrm{~N}-\mathrm{H}), 1705,1643(\mathrm{C}=\mathrm{O}, \mathrm{C}=\mathrm{N}$, $\mathrm{C}=\mathrm{C}) ;{ }^{1} \mathrm{H}-\mathrm{NMR}(\delta, \mathrm{ppm}$ and $\mathrm{J}, \mathrm{Hz}): 8.22(2 \mathrm{H}, \mathrm{d}, 3 \mathrm{~J}$ $=8.5, \mathrm{Ar}-\mathrm{H}), 7.50(2 \mathrm{H}, \mathrm{d}, 3 \mathrm{~J}=8.5, \mathrm{Ar}-\mathrm{H}), 6.98(1 \mathrm{H}$, $\left.\mathrm{s}, \mathrm{ClC}_{6} \mathrm{H}_{4} \mathrm{CH}=\right), 5.11\left(2 \mathrm{H}, \mathrm{s}, \mathrm{NH}_{2}\right)$ and $2.31(3 \mathrm{H}, \mathrm{s}$, $\left.\mathrm{CH}_{3}\right) ;{ }^{13} \mathrm{C}-\mathrm{NMR}: 168.8,166.0(\mathrm{C}=\mathrm{O}, \mathrm{C}=\mathrm{N}), 137.8$, 134.4, 133.4, 133.0, 128.7, 123.2 (C aromatic and C olefilic) and $14.5\left(\mathrm{CH}_{3}\right)$. 
General procedure for synthesis of 1-arylideneamino4-(chlorobenzylidene)-2-methyl-1H-imidazolin5(4H)-one compounds (4a-h)

An equimolar quantity of imidazolin-5-one (3) and a definite aldehyde was refluxed in ethanol for 6.0 hours. The reaction mixture was cooled down to room temperature and the precipitate obtained was filtered off and crystallized from dioxane to give the corresponding products. As the result, yellow crystals are obtained for all cases. Yields, physical properties and IR spectral data of these Schiff's bases were shown in Table 1. ${ }^{1} \mathrm{H}-\mathrm{NMR}$ and ${ }^{13} \mathrm{C}-\mathrm{NMR}$ data of the synthesized Schiff's bases were summarized in Table 2 and 3 , respectively.

\section{Synthesis of 3-(4-chlorophenyl)propanohydrazide (5)}

To a solution of compound (2) $(2.22 \mathrm{~g}, 0.0 \mathrm{l}$ mole) in $30 \mathrm{ml}$ of pyridine, hydrazine hydrate $50 \%$ ( $7.5 \mathrm{~mL}, 0.03$ mole) was added and the reaction mixture was refluxed for 6.0 hours. On cooling, the formed precipitate was filtered off and crystallized from ethanol. Yield $68 \%, \mathrm{mp} \cdot 161-162^{\circ} \mathrm{C}$; IR $(\mathrm{v}$, $\left.\mathrm{cm}^{-1}\right)$ : 3379, 3302 and $3179(\mathrm{~N}-\mathrm{H}), 2924,2855$ (C-Haliphatic), $1700(\mathrm{C}=\mathrm{O}) ;{ }^{1} \mathrm{H}-\mathrm{NMR}: 8.94$ $(1 \mathrm{H}, \mathrm{s}, \mathrm{N}-\mathrm{H}), 7.31(2 \mathrm{H}, \mathrm{d}, 3 \mathrm{~J}=8.5, \mathrm{Ar}-\mathrm{H}), 7.21(2 \mathrm{H}$, $\mathrm{d}, 3 \mathrm{~J}=8.5, \operatorname{Ar}-\mathrm{H}), 4.15\left(2 \mathrm{H}, \mathrm{br}, \mathrm{NH}_{2}\right), 2.80(2 \mathrm{H}, \mathrm{t}$, $\left.3 J=7.5, \mathrm{CH}_{2} \mathrm{CO}\right)$, and $2.31\left(2 \mathrm{H}, \mathrm{t}, 3 \mathrm{~J}=7.5, \mathrm{ArCH}_{2}\right)$; ${ }^{13} \mathrm{C}-\mathrm{NMR}: 170.5(\mathrm{C}=\mathrm{O}), 140.2,130.5,130.1,128.2$ (C aromatic) and 34.8, 30.2 (C aliphatic).

\section{Antimicrobial Activity Assay}

Antimicrobial activity of test samples was assayed using microbroth dilution methods of McKane, L., and Kandel ${ }^{12}$. This means, the serial dilution technique was performed using 96-well microplates to determine the minimum inhibitory concentration (MIC) of the samples against test microorganisms, including Escherichia coli (ATCC 25922), Pseudomonas aeruginosa (ATCC 25923), Bacillus subtilis (ATCC 11774), Staphylococcus aureus subsp. (ATCC 11632), Aspergillus niger (439), Fusarium oxysporum (M 42), Saccharomyces cerevisiae (SH 20) and Candida albicans (ATCC 7754). Briefly, the activated microorganisms were diluted with the growth medium broth (Eugon Broth (Difco, USA) for bacteria, Mycophil (Difco, USA) for fungi) to give a turbidity equivalent to the McFarland 0.5 standard and used for susceptibility testing. The plates were covered and incubated overnight at $37^{\circ} \mathrm{C}$ for bacteria and at $30^{\circ} \mathrm{C}$ for $48 \mathrm{~h}$ for fungi. The lowest concentration which inhibited visible growth of test microorganisms was regarded as MIC. Proper controls were kept for each experiment.

\section{RESULTS AND DISCUSSION}

The most important method for the synthesis of 1-aminoimidazolin-5-one compounds may be treatment of oxazolones with hydrazine. Therefore, as shown in Scheme 1, to obtain 1-amino4-(4-chlorobenzylidene)-2-methyl-1H-imidazolin$5(4 \mathrm{H})$-one, hydrazine hydrate was treated with 4-(4chlorobenzylidene)-2-methyloxazol-5(4H)-one (2), which was prepared by Erlenmeyer condensation of acetyl glycine with 4-chlorobenzaldehyde in presence of sodium acetate and acetic anhydride.

The synthesis of 4-(4-chlorobenzylidene)-2methyloxazol-5(4H)-one(2)from 4-chlorobenzaldehyde and acetyl glycine was carried out according to the method described in our earlier work ${ }^{8,9}$. The structure of the synthesized compound was conformable to its spectral data. According to the literatures, aminoimidazolin-5-one may be afforded by refluxing mixture of oxazolone and hydrazine in pyridine ${ }^{10,11}$. However, the product yielded in the reaction of 4-(4-chlorobenzylidene)-2-methyloxazol-5(4H)one (2) with hydrazine in pyridine was not desired 1-amino-4-(4-chlorobenzylidene)-2-methyl-1Himidazolin-5(4H)-one compound. Mass spectrum of the product showed $\left[\mathrm{M}^{+} \mathrm{H}\right]^{+}$ion peak at $\mathrm{m} / \mathrm{z} 199.0684$ which is not agreement with the molecular formula of the $\mathrm{C}_{11} \mathrm{H}_{10} \mathrm{CIN}_{3} \mathrm{O}(\mathrm{M}=235.0512)$ of 1-amino-4-(4chlorobenzylidene)-2-methyl-1H-imidazolin-5(4H)one. The ${ }^{1} \mathrm{H}-\mathrm{NMR}$ spectrum show the appearance of two adjacent methylene groups as two triplet signals at 2.79 and $2.31 \mathrm{ppm}$ with intensity of $2 \mathrm{H}$ for each signals. The aromatic area appeared two doublet signals, both with intensity of $2 \mathrm{H}$. Besides that, there are two broad signals, one at 8.94 ppm with intensity of $1 \mathrm{H}$ and one at $4.15 \mathrm{ppm}$ with intensity of $2 \mathrm{H}$ corresponding with protons of the hydrazine group $\left(-\mathrm{NHNH}_{2}\right)$. The ${ }^{13} \mathrm{C}-\mathrm{NMR}$ spectrum show the appearance of a signal of carbonyl carbon at 170.5 ppm, four signals of aromatic carbons at 128.2$140.2 \mathrm{ppm}$ and two signals of aliphatic carbons at $30.2-34.8 \mathrm{ppm}$. All data showed that the product is 3-(4-chlorophenyl)propanohydrazide $\left(\mathrm{C}_{9} \mathrm{H}_{11} \mathrm{CIN}_{2} \mathrm{O}\right.$, $M=198.0560)$.

In the our previous work ${ }^{8,9}$, the reaction of oxazole (2) with hydrazine hydrate occurs at room 
temperature to give 2-(acetamido)-3-(4-chlorophenyl) acrylohydrazide easily ${ }^{8,9}$. Thus, we assume that after the formation of the hydrazide, this compound was transformed into N-(3-(4-chlorophenyl)-1-hydrazinyl1-oxopropan-2-ylidene)acetamide, which was reduced by hydrazine to form 3-(4-chlorophenyl) propanohydrazide as description in the Figure 1.

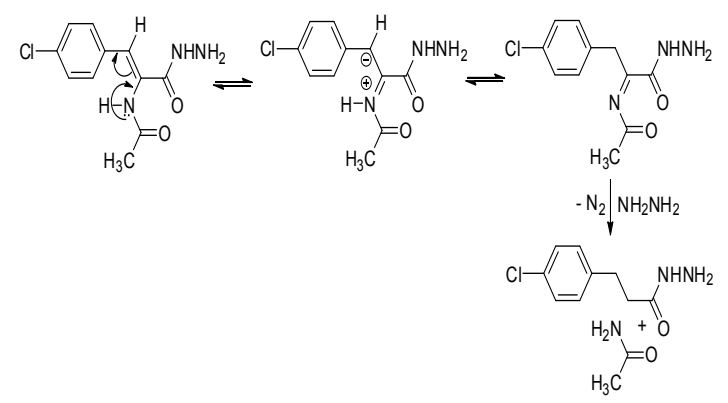

Fig. 1. Proposed mechanism for formation of 3-(4-chlorophenyl)propanohydrazide from 2-(acetamido) -3-(4-chlorophenyl)acrylohydrazide

Changing the condition of reaction, we found out that 1-amino-4-(4-chlorobenzylidene)-2methyl-1H-imidazolin-5(4H)-one compound (3) may be formed by refluxing 4-(4-chlorobenzylidene)2-methyloxazol-5(4H)-one with hydrazine hydrate in ethanol. The structure of the product was first confirmed via its IR spectral data in which the presence of a characteristic absorption band around $3201-3456 \mathrm{~cm}^{-1}$ and a medium one around 1622$1647 \mathrm{~cm}^{-1}$ was in turn represented for $\mathrm{N}-\mathrm{H}$ bonds and $\mathrm{C}=\mathrm{O}$ group. Beside signal of the amino group at $\delta 5.11 \mathrm{ppm}(2 \mathrm{H}$, singlet), signals of benzene ring (two doublet with $J=8.5 \mathrm{~Hz}$ at $\delta 8.22 \mathrm{ppm}$ and $\delta$ $7.50 \mathrm{ppm})$, signal of olefinic proton $(1 \mathrm{H}$, singlet) at $\delta 6.98 \mathrm{ppm}$ and signal of the methyl group $(3 \mathrm{H}$, singlet) at and $\delta 2.31 \mathrm{ppm}$ were also easily detected. Nine signals in the ${ }^{13} \mathrm{C}-\mathrm{NMR}$ spectrum of (3) were considered to be accordant with expected structure of the 1-amino-4-(4-chlorobenzylidene)-
2-methyl-1H-imidazolin-5(4H)-one. The HR-MS of this product showed the molecular ion peak $\left[\mathrm{M}^{+} \mathrm{H}\right]^{+}=236.0637$, which was agreement with mass calculated for $\mathrm{C}_{11} \mathrm{H}_{10} \mathrm{CIN}_{3} \mathrm{O}$ with 235.0512.

1-Amino-4-(4-chlorobenzylidene)-2-methyl$1 \mathrm{H}$-imidazolin-5(4H)-one compound (3) reacted with aromatic aldehydes in absolute ethanol to form azomethine derivatives (4a-h), respectively. Yields, physical properties and IR spectral data of these azomethines were shown in Table 1. The IR spectra of Schiff's bases (4a-h) obtained from amine (3) showed not only a lack of stretching band at $3227-3424 \mathrm{~cm}^{-1}$ $\left(\mathrm{vNH}_{2}\right)$ but also an appearance of the absorption band of imine group $(\mathrm{C}=\mathrm{N})$ around $1645-1666 \mathrm{~cm}^{-1}$. ${ }^{1} \mathrm{H}-\mathrm{NMR}$ spectra of (4a-h) compounds show a new signal observed at 9.44-10.07 ppm integrating for the proton of the azomethine group $(\mathrm{CH}=\mathrm{N})$ (see Table 2). In the HMBC spectra (see the example of the HMBC correlations of $(4 \mathrm{~g})$ compound shown in the Fig. 2), the singlet around 9.44-10.07 ppm in the ${ }^{1} \mathrm{H}-\mathrm{NMR}$ spectra made cross peak with signals of carbon atoms in the benzene ring of benzylidene moiety bonded to nitrogen. The values of chemical shift of the azomethine protons were also similar to values of chemical shift of these protons in the ${ }^{1} \mathrm{H}$-NMR of 1 -arylideneamino-4-arylidene2-phenyl-1H-imidazolin-5(4H)-one compounds ${ }^{10}$. Using the HSQC and HMBC spectra, the other ${ }^{13} \mathrm{C}$ signals of the Schiff's bases were assigned and summarized in Table 3.

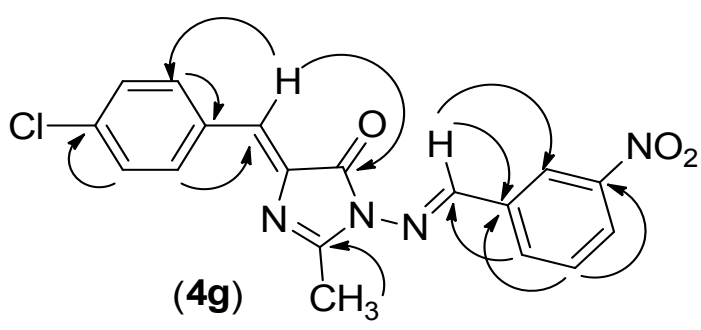

Fig. 2. The HMBC correlations of the $(4 \mathrm{~g})$ compound

Table 1: Physical and IR spectral data of the Schiff's bases (4a-h)

\begin{tabular}{|c|c|c|c|c|c|c|}
\hline \multirow[t]{2}{*}{ (Comp.)/X } & \multirow[t]{2}{*}{ M.p. $\left({ }^{\circ} \mathrm{C}\right)$} & \multirow[t]{2}{*}{ Yield(\%) } & \multicolumn{3}{|c|}{$\mathrm{IR}\left(v, \mathrm{~cm}^{-1}\right)$} & \multirow[t]{2}{*}[\mathrm{M}^{+}\mathrm{H}]{$^{+}$[Calc. $]$} \\
\hline & & & $\mathrm{C}-\mathrm{H}$ & $\mathrm{C}=\mathrm{O}$ & $\mathrm{C}=\mathrm{C}, \mathrm{C}=\mathrm{N}$ & \\
\hline$(4 \mathrm{a}) / 4-\mathrm{CH}_{3} \mathrm{O}$ & $176-178$ & 80 & 30602930 & 17171678 & 16051561 & 354.1051 [354.1009] \\
\hline$(4 b) / 4-\mathrm{CH}_{3}$ & $182-184$ & 66 & 29242855 & 17051651 & 1589 & $360.0867 *[360.0880]$ \\
\hline$(4 c) / 2-F$ & $196-197$ & 78 & - & 17171651 & 1591 & 342.0824 [342.0809] \\
\hline$(4 d) / 4-F$ & $184-185$ & 74 & - & 17131651 & 1589 & 342.0818 [342.0809] \\
\hline$(4 \mathrm{e}) / \mathrm{H}$ & $173-174$ & 68 & 2960 & 17131651 & 1589 & $324.0928[324.0904]$ \\
\hline$(4 f) / 2-\mathrm{NO}_{2}$ & $175-177$ & 77 & 2847 & 17051643 & 1582 & 369.0751 [369.0754] \\
\hline$(4 \mathrm{~g}) / 3-\mathrm{NO}_{2}$ & $181-182$ & 81 & 3079 & 1713 & 1589 & $369.0746[369.0754]$ \\
\hline$(4 \mathrm{~h}) / 4-\mathrm{NO}_{2}$ & $213-214$ & 84 & 2924 & 17051643 & 1582 & $369.0783[369.0754]$ \\
\hline
\end{tabular}

*(4b): $\left[\mathrm{M}^{+} \mathrm{Na}\right]^{+}$. 
Additionally, structure of the Schiff's bases conformity with molecular formulas of the desired was further confirmed by HR-MS data. Molecular 1-arylideneamino-4-(4-chlorobenzylidene)-2-methylion peaks in the mass spectra of the products were $1 \mathrm{H}$-imidazolin-5(4H)-one compounds (see Table 1 ).

Table 2: Signals in the ${ }^{1} \mathrm{H}-\mathrm{NMR}$ spectra ( $\delta, \mathrm{ppm}$ and $\left.\mathrm{J}, \mathrm{Hz}\right)$ of the Schiff's bases (4a-h)

\begin{tabular}{|c|c|c|c|c|c|c|c|c|}
\hline$X$ & (4a) & (4b) & (4c) & $(4 d)$ & $(4 e)$ & $(4 f)$ & $(4 g)$ & (4h) \\
\hline Number & $4-\mathrm{CH}_{3} \mathrm{O}$ & $4-\mathrm{CH}_{3}$ & $2-\mathrm{F}$ & $4-\mathrm{F}$ & $\mathrm{H}$ & $2-\mathrm{NO}_{2}$ & $3-\mathrm{NO}_{2}$ & $4-\mathrm{NO}_{2}$ \\
\hline $2 a$ & $2.47, \mathrm{~s}$ & $2.48, s$ & $2.49, \mathrm{~s}$ & $2.48, s$ & $2.49, \mathrm{~s}$ & $2.50, \mathrm{~s}$ & $2.50, \mathrm{~s}$ & $2.52, \mathrm{~s}$ \\
\hline 6 & $7.08, \mathrm{~s}$ & $7.10, \mathrm{~s}$ & $7.06, \mathrm{~s}$ & $7.10, \mathrm{~s}$ & $7.12, \mathrm{~s}$ & $7.12, \mathrm{~s}$ & $7.06, \mathrm{~s}$ & $7.12, \mathrm{~s}$ \\
\hline 8 & $\begin{array}{c}8.24, d \\
J=8.5\end{array}$ & $\begin{array}{c}8.28, d \\
J=8.5\end{array}$ & $\begin{array}{c}8.22, d \\
J=8.5\end{array}$ & $\begin{array}{c}8.29, d \\
J=8.5\end{array}$ & $\begin{array}{c}8.28, d \\
J=8.5\end{array}$ & $\begin{array}{c}8.27, d \\
J=8.5\end{array}$ & $\begin{array}{c}8.20, d \\
J=8.5\end{array}$ & $\begin{array}{c}8.26, d \\
J=8.5\end{array}$ \\
\hline 9 & $\begin{array}{c}7.52, d \\
J=8.5\end{array}$ & $\begin{array}{c}7.55, d \\
J=8.5\end{array}$ & $\begin{array}{c}7.50, d \\
J=8.5\end{array}$ & $\begin{array}{c}7.54, d \\
J=8.5\end{array}$ & $\begin{array}{c}7.55, d \\
J=8.5\end{array}$ & $\begin{array}{c}7.54, d \\
J=8.5\end{array}$ & $\begin{array}{c}7.47, d \\
J=8.5\end{array}$ & $\begin{array}{c}7.53, d \\
J=8.5\end{array}$ \\
\hline 11 & $9.44, \mathrm{~s}$ & $9.52, \mathrm{~s}$ & $9.79, \mathrm{~s}$ & $9.59, \mathrm{~s}$ & $9.58, \mathrm{~s}$ & $10.07, \mathrm{~s}$ & $9.70, \mathrm{~s}$ & $9.75, \mathrm{~s}$ \\
\hline 13 & $7.79, \mathrm{~d} J=8.0$ & $7.75, d \mathrm{~J}=8.0$ & - & $\begin{array}{c}7.95, \mathrm{dd} \\
\mathrm{J}=8.0, \mathrm{~J}=6.0\end{array}$ & $\begin{array}{c}7.87, \mathrm{dd} \\
\mathrm{J}=8.0, \mathrm{~J}=2.0\end{array}$ & - & $8.57, \mathrm{~s}$ & $8.11, \mathrm{~d} J=8.5$ \\
\hline 14 & $\begin{array}{c}7.05, d \\
J=8.0\end{array}$ & $\begin{array}{c}7.32, d \\
J=8.0\end{array}$ & $7.33, \mathrm{~m}$ & $\begin{array}{c}7.37, \mathrm{dd} \\
\mathrm{J}=8.0, \mathrm{~J}=8.0\end{array}$ & $7.55, \mathrm{~m}$ & $8.12, m$ & - & $\begin{array}{c}8.31, d \\
J=8.5\end{array}$ \\
\hline 15 & - & - & $7.58, \mathrm{~m}$ & - & $7.55, \mathrm{~m}$ & $\begin{array}{c}7.76, \mathrm{dd} \\
\mathrm{J} 1=\mathrm{J} 2=8.0\end{array}$ & $8.23, \mathrm{~d} J=8.0$ & - \\
\hline 16 & $\begin{array}{c}7.05, d \\
J=8.0\end{array}$ & $\begin{array}{c}7.32, d \\
J=8.0\end{array}$ & 7.33, m & $\begin{array}{c}7.37, \mathrm{dd} \\
\mathrm{J}=8.0, \mathrm{~J}=8.0\end{array}$ & $7.55, \mathrm{~m}$ & $\begin{array}{c}7.86, \mathrm{dd} \\
\mathrm{J} 1=\mathrm{J} 2=8.0\end{array}$ & $\begin{array}{c}7.77, \mathrm{dd} \\
\mathrm{J} 1=\mathrm{J} 2=8.0\end{array}$ & $\begin{array}{c}8.31, d \\
J=8.5\end{array}$ \\
\hline 17 & $7.79, \mathrm{~d} J=8.0$ & $7.75, d \mathrm{~J}=8.0$ & $\begin{array}{c}7.99, \mathrm{dd} \\
\mathrm{J} 1=\mathrm{J} 2=7.5\end{array}$ & $\begin{array}{c}7.95, \mathrm{dd} \\
\mathrm{J}=8.0, \mathrm{~J}=6.0\end{array}$ & $\begin{array}{c}7.87, \mathrm{dd} \\
\mathrm{J}=8.0, \mathrm{~J}=2.0\end{array}$ & $8.12, \mathrm{~m}$ & $\begin{array}{c}8.29, d \\
J=8.0\end{array}$ & $\begin{array}{c}8.11, d \\
J=8.5\end{array}$ \\
\hline others & $\begin{array}{c}3.84, \mathrm{~s} \\
\left(\mathrm{CH}_{3} \mathrm{OAr}\right)\end{array}$ & $\begin{array}{l}2.37, \mathrm{~s} \\
\left(\mathrm{CH}_{3} \mathrm{Ar}\right)\end{array}$ & - & - & - & - & - & - \\
\hline
\end{tabular}

Table 3: Signals in the ${ }^{13} \mathrm{C}-\mathrm{NMR}$ spectra $(\delta, \mathrm{ppm})$ of the Schiff's bases (4a-h)

\begin{tabular}{|c|c|c|c|c|c|c|c|c|}
\hline X & (4a) & (4b) & (4c) & (4d) & $(4 e)$ & (4f) & $(4 \mathrm{~g})$ & (4h) \\
\hline Number & $4-\mathrm{CH}_{3} \mathrm{O}$ & $4-\mathrm{CH}_{3}$ & $2-\mathrm{F}$ & $4-F$ & $\mathrm{H}$ & $2-\mathrm{NO}_{2}$ & $3-\mathrm{NO}_{2}$ & $4-\mathrm{NO}_{2}$ \\
\hline 2 & 163.3 & 163.6 & 162.8 & 165.3 & 163.6 & 163.3 & 162.6 & 162.9 \\
\hline $2 a$ & 14.8 & 15.2 & 14.5 & 15.2 & 15.2 & 15.1 & 14.5 & 14.7 \\
\hline 4 & 137.2 & 137.3 & 136.8 & 137.2 & 137.2 & 136.9 & 136.6 & 136.7 \\
\hline 5 & 165.6 & 165.9 & 165.6 & 165.9 & 165.9 & 166 & 165.4 & 165.5 \\
\hline 6 & 125.8 & 124.9 & 124.9 & 125 & 125 & 125.5 & 125 & 125.2 \\
\hline 7 & 132.4 & 132.7 & 132.2 & 132.6 & 132.6 & 132.5 & 132.1 & 132.3 \\
\hline 8 & 133.3 & 133.7 & 133.3 & 133.7 & 133.7 & 133.8 & 133.3 & 133.5 \\
\hline 9 & 128.5 & 128.9 & 128.4 & 128.9 & 128.9 & 128.9 & 128.3 & 128.4 \\
\hline 10 & 134.7 & 135 & 134.8 & 135 & 135.1 & 135.2 & 134.8 & 135 \\
\hline 11 & 154.7 & 154.6 & 146.6 & 153.1 & 154.3 & 148.8 & 151.1 & 151 \\
\hline 12 & 124.5 & 130.9 & 126.3 & 130.3 & 133.6 & 131.9 & 135.2 & 139.5 \\
\hline 13 & 129.2 & 127.7 & 160.1 & 130.1 & 129 & 148.5 & 121.3 & 128.5 \\
\hline 14 & 114.3 & 129.6 & 115.3 & 116.1 & 127.7 & 124.7 & 148.1 & 123.7 \\
\hline 15 & 161.8 & 141.6 & 120.9 & 163 & 131.5 & 128.6 & 133.2 & 148.7 \\
\hline 16 & 114.3 & 129.6 & 124.6 & 116.1 & 127.7 & 133.8 & 130.1 & 123.7 \\
\hline 17 & 129.2 & 127.7 & 133 & 130.1 & 129 & 128 & 124.9 & 128.5 \\
\hline others & $\begin{array}{c}55.2 \\
\left(\mathrm{CH}_{3} \mathrm{OAr}\right)\end{array}$ & $\begin{array}{c}21.1 \\
\left(\mathrm{CH}_{3} \mathrm{Ar}\right)\end{array}$ & - & - & - & - & - & - \\
\hline
\end{tabular}


Schiff's bases (4a-f) were examined for antimicrobial activity against Escherichia coli, Pseudomonas aeruginosa (Gram-negative bacteria); Bacillus subtilis, Staphylococcus aureus (Grampositive bacteria); Aspergillus niger, Fusarium oxysporum (mold) and Saccharomyces cerevisiae, Candida albicans (yeast). These compounds were subjected to examination of their MIC values according to the reported method ${ }^{12}$ and the data are shown in Table 4. The two-fold microdilution broth method was used and all of the tested samples demonstrated inhibitory effects in a concentrationdependent manner. However, the results showed that only $4 \mathrm{a}, 4 \mathrm{~b}$ and $4 \mathrm{~h}$ exhibited any significant inhibition against Staphylococcus aureus with MIC values of $100 \mu \mathrm{g} / \mathrm{mL}$.

Table 4: The minimum inhibitory concentrations (MIC) of the Schiff's bases against bacteria and fungi

\begin{tabular}{|c|c|c|c|c|c|c|c|c|}
\hline \multirow[t]{3}{*}{ Sample } & \multicolumn{8}{|c|}{ MICa $(\mu \mathrm{g} / \mathrm{mL})$} \\
\hline & \multicolumn{2}{|c|}{ Bacteria Gr (-) } & \multicolumn{2}{|c|}{ Bacteria $\operatorname{Gr}(+)$} & \multicolumn{2}{|c|}{ Mold } & \multicolumn{2}{|c|}{ Yeast } \\
\hline & E.C & $P . A$ & B.S & $S . A$ & $A . N$ & F.O & S.C & C.A \\
\hline $4 a$ & $(-) b$ & $(-)$ & $(-)$ & 100 & $(-)$ & $(-)$ & $(-)$ & $(-)$ \\
\hline $4 b$ & $(-)$ & $(-)$ & $(-)$ & 100 & $(-)$ & $(-)$ & $(-)$ & $(-)$ \\
\hline $4 c$ & $(-)$ & $(-)$ & $(-)$ & $(-)$ & $(-)$ & $(-)$ & $(-)$ & $(-)$ \\
\hline $4 d$ & $(-)$ & $(-)$ & $(-)$ & $(-)$ & $(-)$ & $(-)$ & $(-)$ & $(-)$ \\
\hline $4 e$ & $(-)$ & $(-)$ & $(-)$ & $(-)$ & $(-)$ & $(-)$ & $(-)$ & $(-)$ \\
\hline $4 f$ & $(-)$ & $(-)$ & $(-)$ & $(-)$ & $(-)$ & $(-)$ & $(-)$ & $(-)$ \\
\hline $4 \mathrm{~g}$ & $(-)$ & $(-)$ & $(-)$ & $(-)$ & $(-)$ & $(-)$ & $(-)$ & $(-)$ \\
\hline $4 \mathrm{~h}$ & $(-)$ & $(-)$ & $(-)$ & 100 & $(-)$ & $(-)$ & $(-)$ & $(-)$ \\
\hline
\end{tabular}

aE.C - Escherichia coli, P.A - Pseudomonas aeruginosa, B.S - Bacillus subtilis, S.A - Staphylococcus aureus, A.N Aspergillus niger, F.O - Fusarium oxysporum, S.C - Saccharomyces cerevisiae and C.A - Candida albicans. ${ }^{\mathrm{b}} \mathrm{MIC}>100 \mu \mathrm{g} / \mathrm{mL}$ and not determined

\section{CONCLUSION}

Refluxing mixture of 4-(4-chlorobenzylidene) -2-methyloxazol-5(4H)-one and hydrazine hydrate in different solvents forms different products. In ethanol, the product is 1-amino-4-(4-chlorobenzylidene)2-methyl-1H-imidazolin-5-one but in pyridine, the product is 3-(4-chlorophenyl)propanohydrazide.

The reaction of 1-amino-4-(4-chlorobenzylidene) -2-methyl-1H-imidazolin-5-one with aromatic aldehydes yielded eight Schiff's bases, respectively. The structure of the Schiff's bases was determined by IR, ${ }^{1} \mathrm{H}-\mathrm{NMR},{ }^{13} \mathrm{C}-\mathrm{NMR}$ and MS spectral data. Most of the Schiff's bases exhibited low activity against tested microorganisms including Escherichia coli, Pseudomonas aeruginosa (Gram-negative bacteria); Bacillus subtilis, Staphylococcus aureus (Gram-positive bacteria); Aspergillus niger, Fusarium oxysporum (mold) and Saccharomyces cerevisiae, Candida albicans (yeast).

\section{ACKNOWLEDGEMENT}

This research was not supported by any organizations.

\section{Conflict of Interests}

The authors declare that there is no conflict of interests regarding the publication of this paper.

\section{REFERENCES}

1. Shalini, K., Sharma, P. K., Kumar, N. Der Chemica Sinica., 2010, 1(3), 36-47.

2. Bhatnagar A., Sharma P. K., Kumar N. Int. J. Pharm Tech Res., 2011, 3(1), 268-282.

3. Gupta, P., Gupta, J. K. Int. J. Modern Chem., 2015, 7(2), 60-80.

4. Da Silva, C. M., Da Silva, D. L., Modolo, L. V., Alves, R. B., De Resende, M. A., Martins, C. V. B., De Fátima, A. J. Adv. Res., 2011, 2, 1-8.

5. Kajal, A., Bala, S., Kamboj, S., Sharma,
N. and Saini, V. J. Catalysts, Article ID 893512. Available from: http://dx.doi. org/10.1155/2013/893512., 2013.

6. Channe G., Ullas, B.J., Chandrashekar, P. G., Suhas, R., Rakesh, K.P., Avinash, P. J. Chem. Applied Biochem., 2015, 2(1), 116-123.

7. Azab, M. E., Rizk, S. A., Amr, A. E-G. Molecules., 2015, 20, 18201-18218. Available from: https://doi.org/10.3390/molecules 201018201 
8. Nguyen, C. T., Nguyen, D. V., Ta H.T.T., Le H. T. T., Hoang P. T. L., Vuong T. L. A. HCMUE J. Sci., 2014, 58, 20-26.

9. Nguyen, C. T., Nguyen D. D., Truong L. N. A., Truong N. T. Q. Vietnam J. Chem., 2015, 53(6e1, 2), 315-319.

10. Al Abodi, A.-J. K., Majed, N., Sahar, A. K., Al-Bayati, R. I. H. Am. J. Org. Chem., 2012,
2(6), 143-150. Available from: DOI: 10.5923/j. ajoc.20120206.04

11. Al-Soodani, M. A. A., Ali, A. H. M., Al-Marjani, M. F., Atia, A. K. Int. J. Adv. Res., 2014, 2(3), 399-408.

12. McKane, L., Kandel, J. Microbiology: Essentials and Applications. $2^{\text {nd }}$ edition. McGraw-Hill: New York, USA, 1996, 375-406. 